\title{
ESTIMATION OF RATES OF RETURN TO INVESTMENTS IN EDUCATION IN LATVIA
}

\author{
LINDA ROMELE ${ }^{1}$ \\ University of Latvia (Latvia)
}

\begin{abstract}
The aim of the article is to prove the positive impact of education on work salary. For this purpose, the main task of the article is to estimate the Mincer rate of return by taking several factors into account. A secondary task of the research is to analyze the results of 2010 and 2011 and to find explanations for the significant differences between the two years. The results of research and a detailed analysis of the labour market indicate a positive return from attainment of education at an individual level, and they strengthen the hypothesis about a correlation among higher education attainment, higher employment levels and welfare. So far, the Mincer rate of return has not been widely used in Latvia.
\end{abstract}

KEYWORDS: rate of return, education, work salary.

JEL CODES: J01, J31

\section{Introduction}

The purpose of the article is to show the investments efficiency in education where particular tasks are to estimate rates of return in 2010 and 2011 based on Mincer earnings function. Research reveals that Mincer rate of return of men in 2010 was equal to $7.88 \%$ and decreased in 2011 by 0.77 percentage points (in case of women rate of return has decreased by 1.26) and can be explained by decreased wage inequality in 2011 in comparison with 2010.

An estimate of the Mincer rate of return is based on the logarithm earnings function, and it indicates the contribution to work salary of one additional year of schooling. The Mincer earnings function, which is one of the most useful methods for estimating the rate of return, includes several factors, such as number of years of schooling, age of the employee, age of the employee upon entering the labour market, work experience and net earnings. The research data are based on Labour Force Survey data issued by the Central Statistical Bureau of Latvia for 2010 and 2011. The author used several criteria for selecting the data and weighed the data by gender.

Results indicate a significant decrease in the Mincer rate of return in 2011 in comparison with 2010. The author attributes the difference to an increase in work salary in 2011 mainly for people who have obtained secondary education; the work salary for people with higher education, the increase in work salary was comparatively insignificant.

The results are useful in planning education policy because a high rate of return indicates a lack of highly qualified specialists where demand outpaces supply. A high rate of return at an individual level also indicates that individuals should invest more in their education through loans instead of relying on state subsidies.

\footnotetext{
Linda Romele - University of Latvia

E-mail: lindaro@inbox.lv

Tel.: +37129421223
} 


\section{Benefits and costs of education}

Today education is one of the crucial factors for ensuring faster economic recovery and society's wellbeing. The European Commission states that: "Education and training have a fundamental role to play in achieving the 'Europe 2020' objectives of smart, sustainable and inclusive growth..." (The Council of the European Union, 2011).

Therefore, education is considered an important investment with a particular rate of return. The economics of education investigates the economic aspects of education at an individual, as well as societal, level. One way to estimate the rate of return is to use the Mincer earnings function, which has been well known since the 1970's. Before Mincer, Nobel Prize laureate Gary Stanley Becker studied human capital as an important part of economic growth. Mincer used a regression function to estimate the rate of return from education. Independent variables were an individual's age, length of education, work experience and work experience squared; the dependent variable was earnings. Despite criticism of Mincer's earnings function, the model is still used in several research studies to prove the efficacy of investment in education. Today the rate of return from investment in education is studied by Professor Angel de la Fuente and Nobel Prize laureate Professor James Heckman, earlier by Professor David Card, Professor George Psacharopoulos and others. In Latvia the return from investment in education is studied by Professor M. Hazans at the University of Latvia. Specifically the economic return from investment in education is the reason why people decide to invest their financial resources and time in education. Moreover, the return from education is associated with political decisions regarding taxes because a tax system directly impacts the work salary of employees. Surveys prove that education is one of the main prerequisites for success in the labour market (Riddell, 2004: 4).

The Mincer earnings function estimates the rate of return and shows the correlations between schooling, work experience and work salary. In general, the advantages of education are greater at an individual and societal level. M. Friedman was one of the first who wrote about additional advantages of education (Friedman, 1982). The author summarizes the main benefits and costs of education at these levels.

Table 1. Main financial and non-financial benefits and costs of education at individual and societal level

\begin{tabular}{|c|c|c|}
\hline & Individual level & Societal level \\
\hline $\begin{array}{l}\text { Financial } \\
\text { Benefits }\end{array}$ & $\begin{array}{l}\text { - } \text { Higher income } \\
\text { - } \text { Higher probability of being employed } \\
\text { - } \text { Better health and knowledge about health } \\
\text { conditions } \\
\text { - } \quad \text { Higher productivity }\end{array}$ & $\begin{array}{l}\text { - Higher income from labour taxes, including } \\
\text { social tax contribution to the social budget } \\
\text { - } \text { Higher income from consumption taxes } \\
\text { - } \begin{array}{l}\text { Lower social benefits costs (e.g., unemploy- } \\
\text { ment benefits) }\end{array} \\
\text { - Lower cost of health care } \\
\text { - More education may raises not only the } \\
\text { productivity of those receiving the education } \\
\text { but also the productivity of those they work } \\
\text { with and interact with (Riddell)* }\end{array}$ \\
\hline
\end{tabular}




\begin{tabular}{|c|c|c|}
\hline & Individual level & Societal level \\
\hline $\begin{array}{l}\text { Non- } \\
\text { financial } \\
\text { benefits }\end{array}$ & \begin{tabular}{|l} 
- $\begin{array}{l}\text { Higher awareness and comprehension about } \\
\text { advantages and possibilities of education }\end{array}$ \\
- $\begin{array}{l}\text { People enjoy learning and acquiring new } \\
\text { knowledge (Riddell)* }\end{array}$ \\
- $\begin{array}{l}\text { Higher education is associated with longer life } \\
\text { expectancy, better health (Riddell)* }\end{array}$ \\
- $\begin{array}{l}\text { Effect of education on consumer choice effi- } \\
\text { ciency (Riddell) }\end{array}$ \\
- $\begin{array}{l}\text { Effect of education on charitable giving and } \\
\text { volunteer activity (Riddell) }\end{array}$ \\
- Intergenerational effects such as lower \\
fertility, reduced teenage childbearing, more \\
substantial family investments in children, less \\
cost of education, lower criminal propensities \\
in children, improved child health (Riddell) \\
- It is possible that more educated people commit \\
as much crime as less educated people, but are \\
better at avoiding arrest or obtaining lighter \\
sentences (Riddell)* \\
More highly educated people are more likely to \\
use drugs more recently approved (education \\
only matters for individuals who repeatedly \\
purchase drugs for a given condition) (Lleras- \\
Muney, Lichtenberg)*
\end{tabular} & 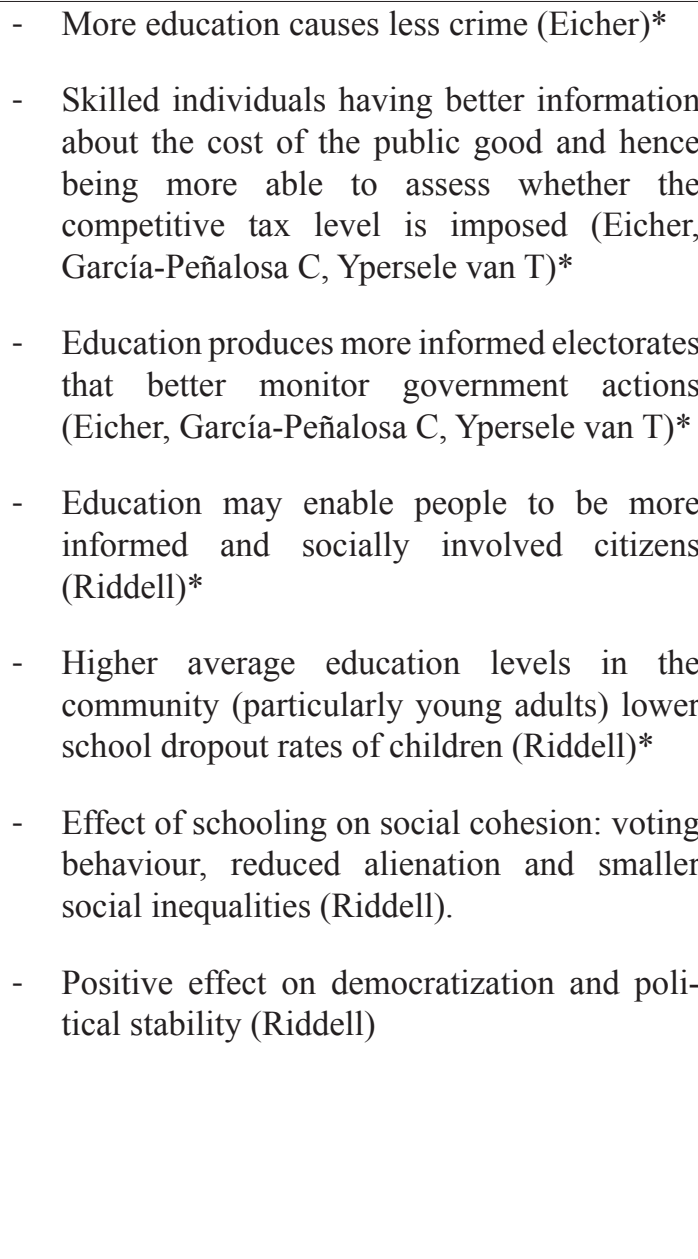 \\
\hline $\begin{array}{l}\text { Financial } \\
\text { Costs }\end{array}$ & $\begin{array}{ll}- & \begin{array}{l}\text { Investments in education (tuition fees, living } \\
\text { expenses, books, etc.) }\end{array} \\
\text { - } & \text { Higher tax payments } \\
\text { - } & \text { Forgone earnings while studying } \\
\text { - } & \text { Schooling may not actually raise cognitive } \\
\text { skills or productivity but schooling may } \\
\text { nevertheless raise the private wage because to } \\
\text { employers it signals a positive characteristic } \\
\text { like ambition or innate ability (Pritchett)* }\end{array}$ & $\begin{array}{l}\text { - Investments in education (salary of teachers, } \\
\text { building maintenance, etc.) } \\
\text { - Forgone income from production while stu- } \\
\text { dying } \\
\text { - Education increases output and hence potential } \\
\text { corruption rents (Eicher, García-Peñalosa C, } \\
\text { Ypersele van T)* }\end{array}$ \\
\hline
\end{tabular}

Source: collected and summarized by author, OECD 2012, Eicher, 2005; Eicher, García-Peñalosa, Ypersele, 2009; Riddell, 2009; Lleras-Muney, Lichtenberg, 2002; Pritchett, 1996

$$
\text { * - original source }
$$

However education has many benefits at individual and societal level, the author detailed will look on relation between work salary and education.

\section{Earnings and education in Latvia - statistical evidence}

Education has a key role in determining an employee's work salary. Education is also related to other factors, such as labour productivity, that affect work salary. An average education level is important in a state 
because it affects the quality of the workforce and its relevance to the needs of the labour market. Moreover, education could favorably affect work experience because accumulated knowledge makes possible to benefit for work experience. Education is also related to the length of a work relationship because better education promotes work rotation and thereby offers better job opportunities and positions.

To some degree, education affects the financial welfare of an enterprise because leaders who are well educated are likely to make strategically correct decisions. Education can also affect the size of an enterprise because better educated employees tend to be more productive and can do the work of several employees.

Table 2. Mean gross monthly earnings by gender, economic activity and educational attainment, 2010, euro

\begin{tabular}{|c|c|c|c|c|}
\hline & $\begin{array}{l}\text { Business } \\
\text { economy, } \\
\text { B-N, Total }\end{array}$ & $\begin{array}{c}\text { Business economy } \\
\text { B-N, } \\
>10 \text { employees }\end{array}$ & $\begin{array}{c}\text { Education and } \\
\text { health*, P-S, } \\
\text { Total }\end{array}$ & $\begin{array}{l}\text { Education and } \\
\text { health*, P-S, } \\
>10 \text { employees }\end{array}$ \\
\hline $\begin{array}{l}\text { Lower secondary or second stage of } \\
\text { basic education (ISCED 2) }\end{array}$ & 437 & 461 & 339 & 341 \\
\hline $\begin{array}{l}\text { Upper secondary and post-secondary } \\
\text { non-tertiary education (ISCED 3-4) }\end{array}$ & 489 & 534 & 409 & 414 \\
\hline $\begin{array}{l}\text { First stage of tertiary education that } \\
\text { is theoretically based / research } \\
\text { preparatory or provides access } \\
\text { to professions with high skills } \\
\text { requirements (ISCED 5A) }\end{array}$ & 880 & 1041 & 707 & 715 \\
\hline $\begin{array}{l}\text { First stage of tertiary education, } \\
\text { programmes which are practically } \\
\text { oriented and occupationally specific } \\
\text { (ISCED 5B) }\end{array}$ & 632 & 724 & 521 & 545 \\
\hline $\begin{array}{l}\text { Second stage of tertiary education } \\
\text { leading to an advanced research } \\
\text { qualification (ISCED 6) }\end{array}$ & 1214 & 1414 & 1254 & 1259 \\
\hline
\end{tabular}

Source: Eurostat

* - education; human health and social work activities; arts, entertainment and recreation; other service activities

In 2010 the work salary of employees with secondary education was $55.57 \%$ of the work salary of employees with higher education (ISCED 5A) in business sectors of all enterprises; in enterprises with more than 10 employees it was $51.3 \%$.

Statistics show that in EU-27 and EU-17 (Eurozone countries) the differences between education levels are lower. For example, in EU-27 earnings of employees with secondary education are $61.22 \%$ of earnings of employees with higher education (ISCED 5A, business sector of enterprises employing more than 10 employees), and $63.04 \%$ in EU-17. This means that higher education in Latvia is more valuable and that employees with secondary education receive a less than average salary. Taking into account these differences, we can conclude that more people should obtain higher education. The share of the population with higher education in the age group of 25 - 64-year-olds in 2010 was $26.9 \%$, which is close to the average in Europe (in EU-27 it was $25.9 \%$, and in EU-15 it was $27.3 \%$ ).

\section{Opinion of society}

In accordance with questions developed by the author and SKDS, the leading marketing and public opinion research centre, SKDS conducted a survey in February 2012 in Latvia. A total of 1,060 respondents between the ages of 15 and 74 were surveyed. Results show that only slightly more than half (53\%) agree that more education guarantees higher earnings (answers - definitely guarantees and probably guarantees) 
while $38 \%$ of respondents think that more education does not guarantee higher earnings (answers - probably does not guarantee and definitely does not guarantee).

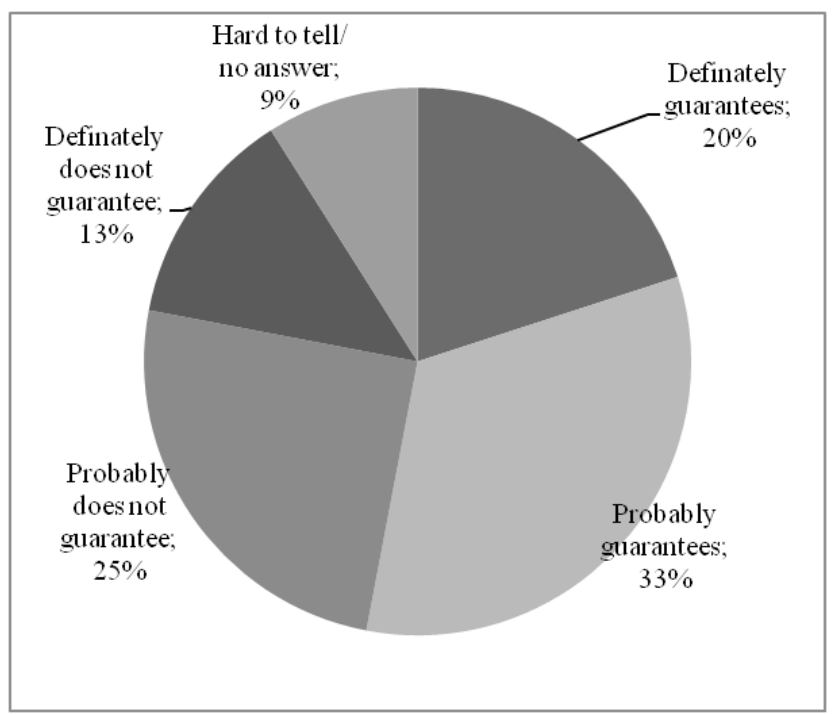

Figure 1. Public opinion on education and earnings.

Source: SKDS, 2012

Pupils and students (77\%), inhabitants with above-average incomes (LVL 170-239, 66 \%) inhabitants with higher education (62\%) and those who live in Riga see a positive correlation between more education and higher income. It is interesting that women (59\%) see a positive correlation more often than do men (47\%); it means that education plays a significant role for women and that more education probably has a higher rate of return among women. The survey also shows that respondents with more education have higher income. For example, $83 \%$ of respondents with low incomes (LVL 99 and less) have pre-school, primary or secondary education, $53 \%$ of respondents with high incomes (LVL 240 and more) have upper secondary education, and $42 \%$ have higher education - bachelor's degree, master's degree or postgraduate education.

According to the survey, $43 \%$ of Latvia's inhabitants started their careers (concluded a labour contract for the first time) at 18-20 years of age while $24 \%$ entered the labour market at 14-17 years of age. In the author's opinion, that is a high indicator. Only $12 \%$ entered the labour market at 21-23 years of age, and only $2 \%$ entered it at 24-26 years of age. It is significant that the age when individuals started their careers has increased from year to year; individuals today are starting their careers later than did older inhabitants in the past. That is proved by the survey results - of respondents in the 25-34 age group, only $14 \%$ entered the labour market at 14-17 years of age, and 55\% entered it at 18-20 years of age. In comparison, $23 \%$ of respondents in the 45-54 age group entered the labour market at 14-17 years of age, and 39\% of respondents in the 55-74 age group entered the labor market at 14-17 years of age.

\section{Estimating rate of return by using the Mincer earnings function}

J. Mincer introduced in the function $\ln y_{s}=\ln y_{0}+r s$ the variable of work experience. Assuming that earnings after schooling are the same at each level of schooling, the function becomes

$y_{s}$ - annual earnings of individual;

$$
\ln Y_{x}=\ln Y_{0}+r s+\beta_{I} x+\beta_{2} x^{2}, \text { where }
$$

$s$ - number of years of schooling;

$r$ - rate of return;

$x$ - number of years of work experience after schooling. 
It should be taken into account that there are several ways of estimating work experience. One way is to use existing work experience; another way is to use the difference between age and number of years of schooling. J. Mincer used the following formula: age minus 6 plus number of years of schooling. In estimating the number of years of schooling in Latvia, the author uses Mincer's approach because data about existing work experience are not available - a consequence of the fact that there were different earnings systems before and after the restoration of Latvia's independence in 1990. The Mincer earnings function compares the earnings of individuals with higher education and lower education levels. The function does not compare the earnings of particular individuals before and after obtaining a particular level of education because such data are not available. Rosen states that function: "helps in thinking about life-cycle aspects of economic inequality" (Rosen, 1992).

Nobel Prize laureate James Heckman considers that rate of return "is a growth rate of market earnings with years of schooling and not an internal rate of return measure" (Heckman, Lochner, Todd, 2005: 3). The author agrees with this statement because the Mincer earnings function does not take into account the direct and indirect costs of education. The Mincer rate of return is interpreted as the rate of return from investments in education; the author assumes that earnings include all benefits from investments in education. In another work Heckman and Carneiro came to conclusion that family welfare and background plays significant role in the rates of return of their children in terms of enrolment in college and costs and availability of funds for education (Heckman, Carneiro, 2003).

The advantage of the Mincer earnings function is the possibility to evaluate the impact of work experience on earnings. Better educated individuals tend to retire later than do less educated individuals. An additional limitation concerns the fact that that education, especially higher education, can be obtained at a later stage of the life cycle - evidence shows that ,postponement of education leads to lower lifetime earnings" (Björklund, Kjellström, 2000: 208). Furthermore, investments made at an early stage of the life cycle increase the productivity of investments at a later stage of the life cycle. Heckman and Jacobs stated that higher rates of return are expected from investments in human capital of the children rather than investments in the human capital of the older workers (Heckman, Jacobs, 2010).

In their study which estimates rates of return, Björklund and Kjellström include only men. They assume that women might interrupt their careers mostly for family reasons and that women are more likely than men to work part time (Björklund, Kjellström, 2000: 197). However during the last years women have started to participate more in labour market and higher labour participation rates foster higher average returns to education (Heckman, Jacobs 2010: 12).

Nowadays Mincer earning function is more often criticized, for example tuition costs and income taxes should be taken into account (Heckman, Lockner, Todd, 2003). Besides Heckman, Lochner and Todd found that log earnings do not increase linearly with schooling. Another disadvantage of Mincer earnings function is lack of knowledge evaluation obtained after formal education like work experience, work place training and informal education.

Rate of return shows wage inequality therefore rates of return are lower in Sweden where wages are compressed and wage inequality is lower. Heckman and Jacobs state that "Income inequality is increasing in part because the returns to education display an upward trend" (Heckman, Jacobs 2010: 7).

Makiko Nakamuro proves that reason of low rate of return is part of competitive and exam-oriented education system in Japan (Nakamuro, 2012). M. Nakamuro in her paper mentioned that children's access to education outside of the school maybe heavily reliant on unobserved family characteristics such as household expenditures. Author assumes that in many cases it is not possible to estimate and evaluate household expenditures. M. Nakamuro shows that educational setting is not the only reason why rate of return is low but governance policy affects the rate of return as well.

A high rate of return implies a lack of highly qualified employees, and that, in turn, increases the work salary and it is related to demand for the skills caused by technological development. Moreover, the rate of return for investment in education has a reciprocal effect - more education means higher earnings while the average number of years of schooling affects higher earnings. Furthermore, the author would like to point 
out that, for the most part, more education does not guarantee a higher income, but it can qualify one for a better position offering a higher income. Investments in education are safer than other types of investments and should be considered as long-term investments.

Author assumes that rate of return could decrease as average years of schooling in Latvia estimated by Barro and Lee methodology has increased during the last decade (approximately from 11.67 years in 2000 to 12.25 in 2010 - average year of schooling of workers in age group 25-64). The average years of schooling is estimated taking into account education level - primary education, secondary education and higher education by 5 years age groups and share of each age group from total population above 25 years. Besides education attainment is increasing - the share of persons with tertiary education attainment was equal to $18.1 \%$ in 2003 while in 2011 the indicator was equal to $27.7 \%$ (Eurostat).

Table 3. Average length of education programs in Latvia

\begin{tabular}{|l|}
\hline Length of education programs in Latvia \\
\hline 0 level -2 years \\
1th - 2nd level -9 years \\
\hline 3rd level $-2-4$ years \\
4th level $-1-3$ years \\
\hline 5th level $-3-6$ years \\
6th level $-3-4$ years \\
\hline
\end{tabular}

Source: Education program in Latvia, National database of education possibilities, www.niid.lv

The author estimated the rate of return by using Labour Force Survey data and applying the Mincer earnings function. In total, the Labour Force Survey contains data about 37,433 individuals. The author made limitation on data and selected data by gender; year of birth (to estimate age, use 2010 minus year of birth); status at main job (selected employees); employment contract or agreement for a specified or unspecified period (selected permanent job for unspecified period); full time or part time (selected full-time job); education level; net work salary in the last month at main job. Those who work and receive a pension at the same time were excluded.

The main challenge of the Mincer earnings function was to combine two different education systems before and after the restoration of independence in 1990. During the Soviet Union era, education consisted of 8 years of basic education, 3 years of secondary education, 3 or 4 years of vocational education, and 5 years of higher education. In 1991, when the new Education Law came into force, the education system was substantially changed. Today there are 9 years of basic education, 3 years of secondary education, from 1 to 4 years of vocational education, and 3 or 4 years of higher education (bachelor's degree). The Labour Force Survey collected data about education levels at 13 different types of education (do not have school education; below primary education; primary education; basic education; general secondary education; general secondary after vocational basic education and training; vocational initial education; vocational basic education and training after basic education; vocational secondary education after basic education; vocational continuing or in-service training programmes after general secondary education; first level of professional higher education or college education; academic higher education (including bachelor and master degree) or second level of professional higher education; doctoral studies) with a particular number of years of schooling. In estimating the rate of return, the author noted the number of years of schooling of those who studied during the Soviet Union era and later during the period if independence.

Applying the above-mentioned criteria, the author selected 6,141 employees; 2,659 of them were men and 3,482 were women. In estimating the rate of return, the author used SPSS 20.0 and Excell 2010.

Using least squares regression, we obtain the Mincer earnings function for men:

$$
\ln Y_{x}=4.519+0.0788 \mathrm{~s}+0.0159 \mathrm{x}-0.00033 \mathrm{x}^{2}, \quad \text { R squared }=0.127
$$


where $r$ is the Mincer coefficient; it equals 0.0788 , or $7.88 \%$, and shows the return from one additional year of schooling in 2010. Work experience in this case has a positive impact; it increases, albeit slowly, during each year of employment.

For women the Mincer earnings function is

$$
\ln Y_{x}=4.303+0.0807 \mathrm{~s}+0.0135 \mathrm{x}-0.00035 \mathrm{x}^{2}, \quad R \text { squared }=0.200,
$$

where $r$ equals to $8.07 \%$, and the rate of return is higher for women than for men.

The work experience premium in Latvia in 2010 was much lower as earnings premium and was equal to $1.35 \%$ for women and $1.59 \%$ for men.

The author estimated the Mincer rate of return for 2011 and compared the results. The Labour Force Survey includes 35,856 records for 2011. Using the same methodology, the author estimated that the rate of return in 2011 for women was $6.81 \%$ (according to the methodology data about 2,722 women); for men the rate of return was $7.11 \%(2,477 \mathrm{men})$. The sample size is representative and estimated coefficients are weighted to general sample (see above-mentioned criteria). However relations between variables are week which can be explained by large sample and different education systems.

$$
\begin{aligned}
& \ln Y_{x}=4.612+0.0681 s+0.0087 \mathrm{x}-0.000194 \mathrm{x}^{2}, \quad R \text { squared }=0.175 \text { (women) } \\
& \ln Y_{x}=4.767+0.0711 \mathrm{~s}+0.0106 \mathrm{x}-0.000226 \mathrm{x}^{2}, \quad R \text { squared }=0.122(\mathrm{men})
\end{aligned}
$$

In analyzing the data of the Labour Force Survey, the author concluded that changes can be explained by reduced inequalities in work salary. In 2011 the work salary of men with secondary education increased, on average, by $10.30 \%$, whereas the work salary of men with higher education increased by only $2.82 \%$. As a result, the rate of return decreased as difference of work salaries between different education levels also decreased.

In accordance with estimates, the Mincer rate of return in 2010 was higher for women. That is not attributable to work salary differences within education levels. For women and men, the work salary of employees with secondary education was approximately $66 \%$ (in case of men) and $70 \%$ (in case of women) of the work salary of employees with higher education (in 2010 approximately $62 \%$ and $64 \%$ ). The author found that the share of women with higher education was $38.4 \%$ in 2010 from sample size but that the share of men with higher education was only $21.99 \%$. At the same time, the net salary for men with higher education in 2010 was higher (LVL 461 from sample) than the salary for women with higher education (LVL 334). As share of women with higher education has increased in 2011 this does not prove the hypothesis that a higher share of employees with higher education increase the rate of return of education.

Results show that work experience has a slight impact on the earnings functions of men and women. Results also indicate an atypical situation: the rate of return for women is higher than rate of return for men in 2010. The correlation coefficient indicates an average close correlation which can be attributed to the large sample size.

\section{Conclusions}

In recent years, the demand for a highly skilled workforce has increased; therefore, the quality of education has become a more significant factor. This, more attention should be paid to wise investments in education because they could give high added value and a high rate of return.

The Mincer rate of return shows a positive rate of return from one additional year of schooling for both men and women. Moreover, results show a positive correlation between more education and a higher rate of return. Although the rate of return decreased in 2011 in comparison with 2010, data reveal less inequality in work salaries. In addition to higher work salary, education has other benefits such as a higher employment rate, better health and greater awareness about education and training opportunities. Education plays 
a crucial role in affecting society in a positive manner. Survey data show that more highly educated people are aware of the positive effects of education, and more people agree that more education guarantees higher earnings.

\section{Acknowledgment}

This work has been supported by the European Social Fund within the project "Support for Doctoral Studies at University of Latvia".

\section{References}

Barro, R. J., Lee, J-Wha. (1993). International Comparisons of Educational Attainment. Journal of Monetary Economics, Elsevier, Vol. 32(3), p. 363-394. Website: http://www.nber.org/papers/w4349

Becker, S. G. (1975). Human Capital: A theoretical and Empirical Analysis, with Special Reference to Education. 2nd edition. National Bureau of Economic Research, p. 13-44. Website: http://papers.nber.org/books/beck75-1

Björklund, A., Kjellström, C. (2002). Estimating the return to investments in education: how useful is the standard Mincer equation? Economics of Education Reviews, Vol. 21, p. 195-210.

Card, D. (2001). Estimating the Return to Schooling: Progress on Some Persistent Econometric Problems. Econometrica, Vol. 69, No. 5, p. 1127-1160.

Stable URL: http://www.jstor.org/stable/2692217

Free Trade Union Confederation of Latvia (February 2012). Public opinion survey. European Social Fund project "Practical application of labour relations and work safety normative acts in sectors and enterprises. SIA SKDS, Survey available on-line: http://www.lbas.lv/upload/stuff/201203/lbas_x_2012.pdf

Friedman, M. (1982). Capitalism and Freedom. Chicago: University of Chicago Press.

Fuente, de la E. (2003). Human capital in a global and knowledge-based economy, part II: assessment at the EU country level. Final report for the European Commission, Directorate-General for Employment and Social Affairs. Luxemburg: Office for Official Publications of the European Communities. Website: http://ideas.repec.org/p/aub/ autbar/576.03.html

Hazans, M. (2003). Returns to Education in the Baltic Countries. Baltic International centre for economic policy studies (BICEPS). Working Paper. Website: http://www.biceps.org/sites/default/files/SSRN-id699623_0.pdf

Heckman, J., Carneiro, P. (2003). Human capital policy. National Bureau of Economic Research Working paper No 9495. Website: http://www.nber.org/papers/w9495

Heckman, J. J., Jacobs, B. (2010). Policies to Create and Destroy Human Capital in Europe. In: H. W. Sinn, E. Phelps (eds.). Perspectives on the Performance of the Continental Economies. MIT Press, 2011, p. 253-322. Website: http://www.nber.org/papers/w15742

Heckman, J. J., Lochner, L. J., Todd, P. E. (2003). Fifty Years of Mincer Earnings Regressions. National Bureau of Economic Research Working paper No. 9732. Website: http://www.nber.org/papers/w9732

Heckman, J. J., Lochner, L. J., Todd, P. E. (2005). Earnings Functions, Rates of Return and Treatment Effects: The Mincer Equation and Beyond. IZA Discussion Paper No. 1700. Website: http://www.iza.org/en/webcontent/publications/papers/viewAbstract?dp_id=1700

Lleras-Muney, A., Lichtenberg, F. R. (2002). The Effect of Education on Medical Technology Adoption: Are the More Educated More Likely to Use New Drugs? National Bureau of Economic Research Working paper, No. 9185. Website: http://www.nber.org/papers/w9185

Mincer, J. (1974). Schooling, experience and earnings. Columbia University Press: New York. Website: http://papers. nber.org/books/minc $74-1$

Mincer, J. (1981). The Economics of wage floors. National Bureau of Economic Research Working paper No. 804. Website: http://www.nber.org/papers/w0804

Nakamuro, M., Inui, T. (2012). Estimating the Returns to Education Using a Sample of Twins - The case of Japan. The Research Institute of Economy, Trade and Industry. Discussion Paper 12-E-076. Website: www.rieti.go.jp/jp/ publications/dp/12e076.pdf

National database of education possibilities. Website: www.niid.lv

OECD. Education at a Glance. (2012). Website: http://www.oecd-ilibrary.org/education/education-at-a-glance-2012 eag_highlights-2012-en 
Pritchett, L. (1996). Where Has All the Education Gone? The World Bank Economic Review, Vol. 15 (3), p. $367-391$. Policy Research Department. Policy research working paper No. 1581. Website: http://elibrary.worldbank.org/ content/workingpaper/10.1596/1813-9450-1581

Psacharopoulos, G. (1981). Returns to Education: An Updated International Comparison. Comparative Education, Vol. 17, No. 3 (Oct., 1981), p. 321-341. Website: Stable URL: http://www.jstor.org/stable/3098688

Psacharopoulos, G. (2007). The effects of education on employment, wages and productivity: a European perspective. European Expert Network on Economics of Education (EENEE). Thematic review, Brussels.

Riddell, W. C. (2004). The Social Benefits of Education: New Evidence on an Old Question. Paper prepared for the conference "Taking Public Universities Seriously". University of Toronto, December 3-4, Website: http://www. utoronto.ca/president/04conference/downloads/Riddell.pdf

Rosen, S. (1992). Distinguished fellow - Mincering labour Economics. The Journal of Economic Perspectives, Vol. 6, No. 2 (Spring), p. 157-170.

Stable URL: http://www.jstor.org/stable/2138414

The Council of the European Union. (2011). Council conclusions on the role of education and training in the implementation of the 'Europe 2020' strategy (2011/C 70/01). Website: http://eur-lex.europa.eu/LexUriServ/LexUriServ.do ?uri=OJ:C:2011:070:0001:0003:EN:PDF

\title{
INVESTICIJŲ I IŠSILAVINIMĄ GRĄŽOS VERTINIMAS LATVIJOJE
}

\author{
Linda ROMELE \\ Latvijos universitetas (Latvija)
}

\section{Santrauka}

Šio straipsnio tikslas - įrodyti išsilavinimo poveiki atlyginimo už darbą dydžiui. Pagrindinis uždavinys apskaičiuoti Mincer grąžos normą įvertinant keletą veiksnių. Kitas tyrimo uždavinys - išnagrinèti 2010 ir 2011 metų rezultatus ir nustatyti ryškių skirtumų tarp šių metu priežastis. Tyrimo rezultatai ir detali darbo rinkos analizè parodè, kad individualiame lygmenyje egzistuoja teigiama graža iš išsilavinimo, tai patvirtina hipotezę apie koreliaciją tarp aukštesnio išsilavinimo ir didesnio užimtumo bei gerovès. Iki šiol Mincer grąžos norma Latvijoje plačiai netaikyta.

PAGRINDINIAI ŽODŽIAI: gražos norma, išsilavinimas, darbo užmokestis.

JEL KLASIFIKACIJA: J01, J31 